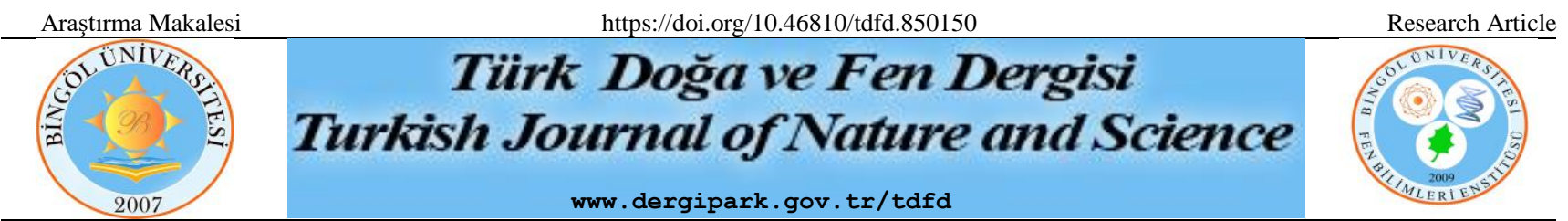

\title{
Evaluation of Antioxidant and Protective Role of Hawthorn Fruit Lyophilized Extract Against Carbon Tetrachloride Toxicity in Rat
}

\author{
Murat ALTINBAŞAK ${ }^{1}$, İsmail ÇELİ ${ }^{2 *}$ \\ ${ }^{1}$ Van Yüzüncü Yıl Üniversitesi, Tıp Fakültesi, Dursun Odabaş Tıp Merkezi, Van, Türkiye \\ ${ }^{2}$ Van Yüzüncü Yıl Üniversitesi, Fen Fakültesi, Moleküler Biyoloji ve Genetik Bölümü, Van, Türkiye \\ Murat ALTINBAŞAK ORCID No: 0000-0001-9058-1424 \\ İsmail ÇELİK ORCID No: 0000-0003-2199-6348 \\ *Corresponding author: icelik@yyu.edu.tr
}

(Alınış: 30.12.2020, Kabul: 01.07.2021, Online Yayınlanma: 31.12.2021)

\begin{abstract}
Keywords
Carbon tetrachloride,

Hawthorn

Fruit,

Protective and

Antioxidant

role

Abstract: This manuscript has aimed to investigate the nephro-hepato protective potential and antioxidant role of lyophilized extract of hawthorn (Crataegus orientalis L) fruit (LEH) against carbon tetrachloride $\left(\mathrm{CCl}_{4}\right)$ toxicity. The experimental were conducted as; $0.5 \mathrm{ml} / \mathrm{kg} \mathrm{CCl}$, bw), $100 \mathrm{mg} / \mathrm{kg} \mathrm{LEH} \mathrm{bw,} 200 \mathrm{mg} / \mathrm{kg} \mathrm{LEH}$ bw, $\mathrm{CCl}_{4} 0.5 \mathrm{ml} / \mathrm{kg}+100 \mathrm{mg} / \mathrm{kg} \mathrm{LEH} \mathrm{bw} \mathrm{and} \mathrm{CCl}_{4} 0.5$ $\mathrm{ml} / \mathrm{kg}+200 \mathrm{mg} / \mathrm{kg} \mathrm{LEH} \mathrm{bw} \mathrm{treated} \mathrm{with} \mathrm{the} \mathrm{extract} \mathrm{for} 3$ weeks. At the end of the experimental treatment, the nephro-hepato protective potential and antioxidant capacity of the LEH was evaluated measuring by liver and kidney damage serum biomarkers, antioxidant defense systems constituents (ADSCs) and malondialdehyde (MDA) content in the erythrocyte, brain, kidney and liver tissues of rats. According to results; liver damage serum enzymes activities and MDA content of the tissues were significantly higher in $\mathrm{CCl}_{4}$ group compared to normal control (NC) whereas; these parameters were significantly lower in extract supplemented groups compared to $\mathrm{CCl}_{4}$ group. According to the resuls, the study results suggest that the LEH supplementations diet restored most of the parameters towards the NC values with fluctuations in the ADSCs. Therefore, it is thought that the extract of hawthorn has antioxidant capacity and hepatoprotective effects against in $\mathrm{CCl}_{4}$-intoxicated rats.
\end{abstract}

\section{Alıç Meyvesi Liyofilize Ekstraktının Sıçanlarda Karbon Tetraklorür Toksisitesine Karşı Antioksidan ve Koruyucu Rolünün Değerlendirilmesi}

Anahtar
Kelimeler
Karbon
tetraklorür,
Alıç meyvesi,
Koruyucu ve
antioksidan rolü

Öz: Bu makale, karbon tetraklorür $\left(\mathrm{CCl}_{4}\right)$ toksisitesine karşı alıç (Crataegus orientalis L.) meyve liyofilize ekstrakt (LEH), böbrek ve karaciğer koruyucu potansiyelini ve antioksidan rolünü araştırmayı amaçlamaktadır. Deneysel dizayn; Normal kontrol (NK) $\mathrm{CCl}_{4}$ grubu $(0,5 \mathrm{ml} / \mathrm{kg}$ $\mathrm{CCl}_{4}$, vücut ağırlı̆̆ bw), $\mathrm{CCl}_{4}+\mathrm{LEH} 1$ grubu $(0,5 \mathrm{ml} / \mathrm{kg}+100 \mathrm{mg} / \mathrm{kg} \mathrm{LEH} \mathrm{bw})$ ve $\mathrm{CCl}_{4}+\mathrm{LEH} 4$ grubu $(0,5 \mathrm{ml} / \mathrm{kg}+$ $200 \mathrm{mg} / \mathrm{kg} \mathrm{LEH} \mathrm{bw)} \mathrm{şeklinde} 3$ haftalık ekstre muamelesi ile yapılmıştır. Deneysel muamelenin sonunda: LEH'nin böbrek ve karaciğer koruyucu potansiyeli ve antioksidan rolünü, karaciğer ve böbrek hasarı serum biyobelirteçleri, eritrosit, beyin, börek ve karaciğerdeki antioksidan savunma sistemleri bileşenleri (ASSB) ile malondialdehit (MDA) içeriği ölçülerek değerlendirildi. Sonuçlara göre; karaciğer hasarı serum enzim aktiviteleri ve dokuların MDA içeriği $\mathrm{CCl}_{4}$ grubunda NK göre anlamlı olarak daha yüksekti. Bu parametreler, ekstre takviyeli gruplarda $\mathrm{CCl}_{4}$ grubuna kıyasla önemli ölçüde daha düşüktü. Sonuçlara göre, LEH takviyeli diyetinin ASSB'lerdeki dalgalanmaları NK değerlerine doğru parametrelerin çoğunu geri çektiğini göstermektedir. Bu nedenle, $\mathrm{CCl}_{4}$ ile toksisite oluşturulan sıçanlarda alıç bitkisi meyve ekstresinin antioksidan kapasiteye ve karaciğer koruyucu etkilere sahip olabileceği düşünülmektedir. 


\section{INTRODUCTION}

Many plants components are used in medicinal purpose for along time. Plant flavonoids are natural molecules of polyphenolic compound of plants. Due to varied effective biological activities and theirs low toxicity the healings effects of these polyphenolic compounds have made be subject of many scientific study. Researcher experes that the plant based rich diet has consistently reduced the risk of several chronic diseases. It is reported that the constituents such as fruit, leave and flower of plants, which are responsible for free radical scavenging role, are especially epicatechin, hyperoside and chlorogenic acid. Also, a lot of studies demonstrated that many aromatic and medical herbs constituents synthesize phytochemicals possessing antioxidant capacity and have been used as a natural product of free radical scavenging molecules $[1,2]$. Also, it has been suggested that many aromatic and medicinal plant spices contain a lot of biological active chemical molecules showing antioxidant role and the properties of herbs are attributed to bioactive phytocompounds as flavonoids, vitamins, phenols, carotenoids, alkaloids, phenolic acids and terpenoids [3]. Many researches support that oxidative damage to proteins DNA and lipids may contribute to the resulting of many illnesses such neurodegenerative, cardiovascular and cancer [4]. So what, it has been declared that the diet based on free radical scavenging role may be important in protection against to much ilness $[4,5]$.

Crataegus orientalis is belongs to Rosaceae family and it is estimated that Crataegus spp include 150 to 1200 species [6]. It had been reported that Crataegus spp. fruit is a rich source of vitamin C, flavanoids, tannin, glycoside, anthocynaidin, saponin and natural antioxidants molecules [7]. Hawthorn fruits are usually eaten fresh by local peoples. Also, the native hawthorn species fruits of are often have been used for the phytotherapy of weak heart disorder, and especially if the illness is accompanied with high blood pressure [8]. Further, it has reported that the essential constituents of hawthorn are organic acids, proanthocyanidins, flavonoids and some amines. Also, it is speculates that some $C$. orientalis may be good antioxidants. They are also among the best anti lipoperoxidants [9-11]. However, it has been reported that the consumption of $C$. orientalis also cause a case of multisystem hypersensitivity reaction and progressive acute renal [12]. In addition, it was reported that $C$. orientalis significantly inhibited carrageenan-induced mice tail thrombosis in vivo [13].

Many plants flavonoids and natural polyphenolic components are currently used in medicinal treatment. Since little is known relatively about the therapeutic of the plant's molecules used in different purpose they have been studied extensively to determinate varied biological activities and their toxicity effect in the last time. The aim of this study was to elevuate healings potential of $C$. orientalis against induced nephrotic and hepatic toxicity with $\mathrm{CCl}_{4}$ by evaluating protective capacity as liver and kidney damage serum biomarkers and ADSCs in the brain, kidney and liver tissues of rats.

\section{MATERIALS and METHODS}

\subsection{Chemicals}

Technical greate of chemicals used during this study were supplied from Sigma Chemical Co. (St. Louis, MO, USA). Kits for superoxide dismutase (SOD) and glutathione peroxidase (GPx) analysis were supplied by Randox Laboratories Ltd and Paraoxonase (PO1) was supplied from Rel Assay Diagnostics kit.

\subsection{Animals}

Thirty six Wistar albino rats with aged 3-4 months and an average weighing 150-250 g were provided from Van Yüzüncü Yıl University Experimental Animal Research Center. and The rats were placed in standard plastic rat cages and were adapted to the laboratory conditions and kept at $22 \pm 2{ }^{\circ} \mathrm{C}$ in a 12 -hour photoperiod during the experiment. The authors decelerate that they have followed EU standards regulations for the protection of animals during experiment and approved by The Local Ethics Committee of Experimental Animal with 24.03.2016 and 2016/03 protocol number.

\subsection{Preparation of lyophilized extract of $C$. orientalis fruit}

Briefly, C. orientalis fruit was supplied from a local producer in Edremit producing province of Van Turkey. Freshly harvested hawthorn fruit was washed with distilled water, and then the fresh hawthorn fruit were dried at room temperature $\left(26 \pm 2{ }^{\circ} \mathrm{C}\right)$. The fruit material was powdered using blender. The aqueous extract of the plant fruit was prepared using the method described by Dalar and Konczak [14]. To obtain the lyophilized plant extract, the fruit aqueous extract was put into falcon tube and freeze-dried under $0.030 \mathrm{mBar}$ a vacuum at $-54{ }^{\circ} \mathrm{C}$ for 3 days.

\subsection{Experimental Design}

The rats used in this experimental study were divided into 6 groups which is one containing 6 rats.

\subsubsection{Normal control (NC)}

Nothing was applied to the group rats. The rats were fed only with standard rat feed and water as ad libitum.

\subsubsection{5 mL Carbon tetrachloride $\left(\mathrm{CCl}_{4}\right)$}

This group rats were received i.p. injection of $\mathrm{CCl} 4$ in olive oil (1:1) at a dose of $0.5 \mathrm{~mL} / \mathrm{kg} \mathrm{CCl} 4$ and fed with standard rat feed and water as ad libitum. The dose of $\mathrm{CCl}_{4}$ was selected on the basis of a $0.5 \mathrm{~mL} / \mathrm{kg}$ bw at which caused nephrotic, hepatic toxicity and oxidative stress [15]. 


\subsection{3. $100 \mathrm{mg} / \mathrm{kg} \mathrm{bw,} \mathrm{LEH} \mathrm{(LEH1)}$}

This group rats were fed only with standard rat feed and water as ad libitum and were received with the extract supplementation $(100 \mathrm{mg} / \mathrm{kg}$, bw) by an oral gastric gavage per day during 21 days.

\subsection{4. $200 \mathrm{mg} / \mathrm{kg} \mathrm{bw} \mathrm{LEH} \mathrm{(LEH2)}$}

This group rats were fed only with standard rat feed and water as ad libitum and were treated with the extract supplementation $(200 \mathrm{mg} / \mathrm{kg}$, bw) by an oral gastric gavage per day during 21 days.

\subsection{5. $0.5 \mathrm{~mL} \mathrm{CCl}_{4} / \mathrm{kg} \mathrm{bw}+100 \mathrm{mg} / \mathrm{kg}$ bw LEH $\left(\mathrm{CCl}_{4}+\mathrm{LEH1}\right)$}

This group rats were received i.p. injection of $\mathrm{CCl} 4$ in olive oil (1:1) at a dose of $0.5 \mathrm{~mL} / \mathrm{kg} \mathrm{CCl}_{4}$ and were treated with the extract supplementation $(100 \mathrm{mg} / \mathrm{kg}$, bw) by an oral gastric gavage per day during 21 days.

\subsection{6. $0.5 \mathrm{~mL} \mathrm{CCl}_{4} / \mathrm{kg} \mathrm{bw}+200 \mathrm{mg} / \mathrm{kg}$ bw LEH $\left(\mathrm{CCl}_{4}+\mathrm{LEH} 2\right)$}

This group rats were received i.p. injection of $\mathrm{CCl} 4$ in olive oil (1:1) at a dose of $0.5 \mathrm{~mL} / \mathrm{kg} \mathrm{CCl}_{4}$ and were treated with the extract supplementation $(200 \mathrm{mg} / \mathrm{kg}$, bw) by an oral gastric gavage per day during 21 days.

\subsection{Preparation of Tissues Supernatant and Erythrocyte Pellets}

The rats knocked out by injection of ketamine $(10 \mathrm{mg} /$ $100 \mathrm{~g}$, bw) intraperitoneally at the end of the 21 days experiment and sacrificed after the necessary samples are taken. Blood were taken from a cardiac puncture using syringe to determinate of serum biomarkers as serum aspartate aminotransferase (AST), alanine aminotransferase (ALT), lactate dehydrogenase (LDH) enzymes, total cholesterol (TC), total protein (TP) creatinine (CRE) and urea levels. For preparation of erythrocytes packet; $1 \mathrm{~mL}$ of blood wit EDTA was taken to another test tube and $2 \mathrm{~mL}$ saline $(0.9 \% \mathrm{NaCl})$ was added. Then they were centrifuged at $3000 \mathrm{rpm}$ at $+4{ }^{\circ} \mathrm{C}$ in a cooled centrifuge for 15 minutes to separate. After centrifugation, the resulted plasma was discarded from the erythrocytes packet, and each time an equal amount of saline $(0.9 \% \mathrm{NaCl})$ was added to the remaining volume and this process was repeated three times. GSH level and MDA content was performed immediately in the erythrocyte packet. The remaining erythrocyte pellet was stored in the deep freeze at $-80^{\circ} \mathrm{C}$ until analysis. Meanwhile, the brain, kidney and liver tissues of rats washing the tissues with physiological saline $(0.9 \%$ $\mathrm{NaCl}$ ) were disected and put in storage falcon tube ant kept at $-80^{\circ} \mathrm{C}$ during the analysis.

For preparation of supernatant extraction of tissues; briefly, $500 \mathrm{mg}$ the tissue sample were weighed and $5 \mathrm{ml}$ cold buffer containing $0.32 \mathrm{~mol} / \mathrm{L}$ sucrose, $1 \mathrm{mmol} / \mathrm{L}$ EDTA, $10 \mathrm{~nm} / \mathrm{L}$ Tris $\mathrm{HCl}(\mathrm{pH} 7.4)$ was added. The tissues were thoroughly crushed with glass baguette and homogenized for 3 minutes in ultrasonic homogenizer. The homogenate was immediately centrifuged for 30 minutes at $9500 \mathrm{rpm}$ at $+4{ }^{\circ} \mathrm{C}$. The clear supernatants from obtained the tissue were used for analysis of ADSCs such as Paraoxonase (PON1) Catalase (CAT) Superoxide dismutase (SOD) Glutathione peroxidase (GPx) Glutathione $S$-transferase (GST) activities, Reduced glutathione (GSH) level and Malondialdehyde (MDA) content [16-18].

\subsection{Biochemical Analysis}

MDA contents was determined using the method described by Jain et al [19] based on TBA reactivity. GSH levels were measured using the method described by Beutler et al [20]. GST was assayed as described by Mannervik \& Guthenberg [21]. GPx was assayed based on that of the rate of the oxidation of glutathione by cumene hydroperoxide [22]. SOD activity was measured by calculating inhibition percentage of formazan dye formation at $505 \mathrm{~nm}$ [23]. CAT activity was measured using the method described by Aebi [24]. PON1 activity was measured by reading the absorbances with a spectrophotometer (Genesys 10 UV Scanning UV/VIS Spectrophotometer; Shimadzu) using kits (Rel Assay Diagnostics kit; Mega Tip) [25]. On the other hands, serum biomarkers releate to liver and kidney damage as AST, ALT, LDH enzyme activities, TC, TP CREA and urea levels were measured by an auto analyzer (BM/HITACHI-911) using the kits.

\subsection{Analysis of Data}

The statistical analyses were made using the Minitab 13 program for MS Windows. One-way analysis of variance (ANOVA) statistical test was used to determine the differences between means of the experimental groups accepting the significance level at $p \leq 0.05$. All statistical data were expressed as mean \pm standard deviation (SD).

\section{RESULTS and DISCUSSION}

Following the experimental treatment, nephro-hepato protective capacity and antioxidant activity of the LEH supplemented diet against to the toxicity of $\mathrm{CCl}_{4}$ were evaluated by liver and kidney damage index of serum biomarkers, ADSCs and MDA content of the rat tissues. According to the obtained data, liver damage index of serum biomarkers suh as AST, ALT and LDH levels of $\mathrm{CCl}_{4}$ group were significantly increased as compared with the control group whereas these biomarkers levels of LEH supplementation grups resulted in a signifanse decrease (Table I). With regard to ADSCs changes, while $\mathrm{CCl}_{4}$ caused fluctuations in ADSCs by oxidative stress condition in the rats, the treatment of the extract supplementations restored the $\mathrm{CCl}_{4}$ induced and fluctuated antioxidant system towards near normal particularly in the tissues of rats. In addition, the imbalance between increased MDA content of tissues due to oxidative stress induced by $\mathrm{CCl}_{4}$ in the all tissues was found to be decreasing in the tissues the extract treated groups (Table II). 
Table I: Effect of $\mathrm{CCl}_{4}$ and $C$. orientalis fruit aqueous extract supplementations on body weight, food and water intake and serum biomarker

\begin{tabular}{|c|c|c|c|c|c|c|}
\hline \multirow[b]{2}{*}{ Parameters } & \multicolumn{6}{|c|}{ GRUPS } \\
\hline & $\begin{array}{l}\mathrm{NC} \\
\mathrm{X} \pm \mathrm{SD}\end{array}$ & $\begin{array}{l}\mathrm{CCl}_{4} \\
\mathrm{X} \pm \mathrm{SD}\end{array}$ & $\begin{array}{l}\mathrm{LEH} 1 \\
\mathrm{X} \pm \mathrm{SD}\end{array}$ & $\begin{array}{l}\mathrm{LEH} 2 \\
\mathrm{X} \pm \mathrm{SD}\end{array}$ & $\begin{array}{l}\mathrm{CCl}_{4}+\mathrm{LEH} 1 \\
\mathrm{X} \pm \mathrm{SD}\end{array}$ & $\begin{array}{l}\mathrm{CCl}_{4}+\mathrm{LEH} 2 \\
\mathrm{X} \pm \mathrm{SD}\end{array}$ \\
\hline \multicolumn{7}{|l|}{ Body weight (g) } \\
\hline Beginning & $176,0 \pm 34$ & $186,2 \pm 25,3$ & $195,3 \pm 41,4$ & $194,7 \pm 31,1$ & $203 \pm 30,2$ & $181,7 \pm 34,2$ \\
\hline Finally & $214,3 \pm 14,4^{*}$ & $208,7 \pm 17$ & $230 \pm 37,7$ & $235 \pm 17,9^{*}$ & $225,3 \pm 24,8$ & $208 \pm 18,6$ \\
\hline \multicolumn{7}{|l|}{ Food and water intake (Day) } \\
\hline $\begin{array}{l}\text { Food intake }(\mathrm{g}) \\
\text { Water intake }(\mathrm{mL})\end{array}$ & $\begin{array}{l}19,2 \pm 1,9 \\
31,4 \pm 4,3\end{array}$ & $\begin{array}{l}15,7 \pm 2,7^{*} \\
23,5 \pm 3,5^{*}\end{array}$ & $\begin{array}{l}18,6 \pm 1,5 \\
33,2 \pm 3,4\end{array}$ & $\begin{array}{l}17,8 \pm 1,6 \\
31,7 \pm 3,8\end{array}$ & $\begin{array}{l}13,7 \pm 2,8^{*} \\
24,3 \pm 4,5^{*}\end{array}$ & $\begin{array}{l}14,8 \pm 3^{*} \\
25 \pm 4,6^{*}\end{array}$ \\
\hline ALT (U/L) & $27,50 \pm 2,42$ & $31,50 \pm 2,34^{\mathrm{a}}$ & $25,33 \pm 4,84$ & $28,50 \pm 1,87$ & $25,83 \pm 2,31^{\mathrm{b}}$ & $28,67 \pm 4,13$ \\
\hline $\operatorname{AST}(\mathrm{U} / \mathrm{L})$ & $143,83 \pm 12,29$ & $189,33 \pm 3,01^{\mathrm{a}}$ & $144,33 \pm 3,78$ & $169,17 \pm 2,79^{\mathrm{a}}$ & $140,50 \pm 3,62^{\mathrm{b}}$ & $122,17 \pm 3,06^{\mathrm{ab}}$ \\
\hline UREA (mg/dL) & $53,17 \pm 5,19$ & $48,67 \pm 4,41$ & $41 \pm 2,61^{\mathrm{a}}$ & $43,17 \pm 2,40^{\mathrm{a}}$ & $46 \pm 3,16^{\mathrm{a}}$ & $45,50 \pm 3,73^{\mathrm{a}}$ \\
\hline $\mathrm{CRE}(\mathrm{mg} / \mathrm{dL})$ & $0,49 \pm 0,05$ & $0,50 \pm 0,08$ & $0,46 \pm 0,05$ & $0,50 \pm 0,07$ & $0,43 \pm 0,04$ & $0,49 \pm 0,04$ \\
\hline $\mathrm{LDH}(\mathrm{U} / \mathrm{L}$ & $1288,83 \pm 37,92$ & $2508 \pm 99,80^{\mathrm{a}}$ & $1646,67 \pm 54,87^{\mathrm{a}}$ & $1521,67 \pm 163,58^{\mathrm{a}}$ & $2275,83 \pm 270,71^{\mathrm{a}}$ & $1835 \pm 52,44^{\mathrm{ab}}$ \\
\hline
\end{tabular}

* Significantly different from beginning, ${ }^{\text {a }}$ : Groups are different significantly from control, ${ }^{\text {b}}$ : Groups are different significantly from $\mathrm{CCl}_{4}$

Table II. Effect of $\mathrm{CCl}_{4}$ and $C$. orientalis fruit aqueous extract supplementations on lipid peroxidation and antioxidant defense systems constituens

\begin{tabular}{|c|c|c|c|c|c|c|c|}
\hline & & & & GROUPS & & & \\
\hline Tissues & Parameters & $\begin{array}{c}\mathrm{NC} \\
\mathrm{X} \pm \mathrm{SD}\end{array}$ & $\begin{array}{c}\mathrm{CCl}_{4} \\
\mathrm{X} \pm \mathrm{SD}\end{array}$ & $\begin{array}{l}\mathrm{LEH} 1 \\
\mathrm{X} \pm \mathrm{SD}\end{array}$ & $\begin{array}{l}\mathrm{LEH} 2 \\
\mathrm{X} \pm \mathrm{SD}\end{array}$ & $\begin{array}{c}\mathrm{CCl}_{4}+\mathrm{LEH} 1 \\
\mathrm{X} \pm \mathrm{SD}\end{array}$ & $\begin{array}{c}\mathrm{CCl}_{4}+\mathrm{LEH} 2 \\
\mathrm{X} \pm \mathrm{SD}\end{array}$ \\
\hline \multirow{7}{*}{ 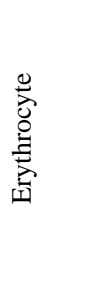 } & $\operatorname{MDA}(\mathrm{nmol} / \mathrm{ml})$ & $16,73 \pm 4,97$ & $31,95 \pm 8,16^{\mathrm{a}}$ & $15,43 \pm 6,62$ & $16,51 \pm 3,85$ & $29,76 \pm 5,22^{\mathrm{a}}$ & $30,34 \pm 7,85^{\mathrm{a}}$ \\
\hline & $\mathrm{GSH}(\mathrm{mg} / \mathrm{ml})$ & $3,92 \pm 0,50$ & $3,60 \pm 0,08$ & $3,26 \pm 0,39^{\mathrm{a}}$ & $3,23 \pm 0,10^{\mathrm{a}}$ & $3,25 \pm 0,46^{\mathrm{a}}$ & $3,53 \pm 0,60$ \\
\hline & GST(U/ml) & $2,27 \pm 0,17$ & $1,90 \pm 0,46$ & $1,83 \pm 0,52$ & $2,08 \pm 0,31$ & $1,99 \pm 0,37$ & $1,90 \pm 0,18^{\mathrm{a}}$ \\
\hline & PON1(U/L) & $127,67 \pm 5,28$ & $112 \pm 7,56^{\mathrm{a}}$ & $89,50 \pm 7,18^{\mathrm{a}}$ & $122,50 \pm 15,41$ & $125 \pm 3,58^{\mathrm{b}}$ & $149,83 \pm 14,55^{\mathrm{ab}}$ \\
\hline & CAT(U/ml) & $163,93 \pm 28,70$ & $213,96 \pm 8,95^{\mathrm{a}}$ & $183,59 \pm 13,89$ & $186 \pm 7,17$ & $183,86 \pm 12,33^{\mathrm{b}}$ & $156,79 \pm 17,53^{b}$ \\
\hline & GPx(U/ml) & $1240,90 \pm 56,18$ & $568,31 \pm 21,35^{\mathrm{a}}$ & $1055,87 \pm 33,09^{\mathrm{a}}$ & $1108,26 \pm 53,50^{\mathrm{a}}$ & $1181,85 \pm 68,91^{\mathrm{b}}$ & $639,48 \pm 106,68^{\mathrm{a}}$ \\
\hline & $\mathrm{SOD}(\mathrm{U} / \mathrm{ml})$ & $2286,07 \pm 13,72$ & $2279,50 \pm 10,09$ & $2282,76 \pm 4,36$ & $2293,77 \pm 8,53$ & $2292,20 \pm 8,95^{\mathrm{b}}$ & $2268,66 \pm 12,24^{a}$ \\
\hline \multirow{7}{*}{ 寻 } & MDA(nmol/g) & $53,64 \pm 10,59$ & $75,44 \pm 8,33^{\mathrm{a}}$ & $43,00 \pm 9,20$ & $61,78 \pm 7,60$ & $73,83 \pm 13,89^{\mathrm{a}}$ & $73,18 \pm 3,37^{\mathrm{a}}$ \\
\hline & $\mathrm{GSH}(\mathrm{mg} / \mathrm{g})$ & $21,64 \pm 1,62$ & $24,13 \pm 4,47$ & $29,81 \pm 3,60^{\mathrm{a}}$ & $27,17 \pm 3,06^{\mathrm{a}}$ & $22,16 \pm 2$ & $24,24 \pm 2,31^{\mathrm{a}}$ \\
\hline & GST(U/g) & $13,62 \pm 2,59$ & $20,08 \pm 2,24^{\mathrm{a}}$ & $20,41 \pm 1,76^{\mathrm{a}}$ & $22,69 \pm 0,33^{\mathrm{a}}$ & $15,48 \pm 1,87^{\mathrm{b}}$ & $19,34 \pm 1,94^{\mathrm{a}}$ \\
\hline & PON1(U/100g) & $13,05 \pm 1,72$ & $6,03 \pm 0,87^{\mathrm{a}}$ & $2,55 \pm 0,29^{\mathrm{a}}$ & $14,93 \pm 0,92^{\mathrm{a}}$ & $3,45 \pm 0,88^{\mathrm{ab}}$ & $13,97 \pm 2,30^{\mathrm{b}}$ \\
\hline & CAT(U/g) & $39,30 \pm 8,02$ & $29,92 \pm 6,76$ & $18,22 \pm 5,57^{\mathrm{a}}$ & $53,87 \pm 10,86^{\mathrm{a}}$ & $49,31 \pm 13,41^{b}$ & $22,11 \pm 4,85^{\mathrm{ab}}$ \\
\hline & GPx(U/g) & $190,68 \pm 8,13$ & $133,44 \pm 6,96^{\mathrm{a}}$ & $180,99 \pm 17,49$ & $202,49 \pm 17,71$ & $90,74 \pm 1,62^{\mathrm{ab}}$ & $151,61 \pm 17,22^{\mathrm{ab}}$ \\
\hline & $\mathrm{SOD}(\mathrm{U} / \mathrm{g})$ & $2203,43 \pm 14,80$ & $2155,26 \pm 7,62^{\mathrm{a}}$ & $2161,84 \pm 14,63^{\mathrm{a}}$ & $2179,75 \pm 17,83^{\mathrm{a}}$ & $2148,24 \pm 19,16^{\mathrm{a}}$ & $2187,82 \pm 14,33^{\mathrm{b}}$ \\
\hline \multirow{7}{*}{$\underset{\Xi}{\stackrel{\partial}{\Xi}}$} & $\mathrm{MDA}(\mathrm{nmol} / \mathrm{g})$ & $60,76 \pm 11,80$ & $82,24 \pm 9,37^{\mathrm{a}}$ & $60,48 \pm 9,46$ & $60,87 \pm 6,39$ & $81,73 \pm 19,97^{\mathrm{a}}$ & $64,65 \pm 10,28^{\mathrm{b}}$ \\
\hline & $\mathrm{GSH}(\mathrm{mg} / \mathrm{g})$ & $65,14 \pm 3,96$ & $70,62 \pm 1,13^{\mathrm{a}}$ & $68,15 \pm 4,98$ & $66,02 \pm 3,45$ & $58,88 \pm 5,22^{\mathrm{ab}}$ & $64,54 \pm 8,65$ \\
\hline & GST(U/g) & $6,83 \pm 1,79$ & $10,51 \pm 1,44^{\mathrm{a}}$ & $7,84 \pm 1,40$ & $7,81 \pm 1,89$ & $6,42 \pm 1,54^{\mathrm{b}}$ & $5,22 \pm 1,06^{\mathrm{b}}$ \\
\hline & PON1(U/100g) & $23,22 \pm 1,67$ & $2,63 \pm 1,07^{\mathrm{a}}$ & $22,93 \pm 2,40$ & $24,56 \pm 2,69$ & $12,10 \pm 1,10^{\mathrm{ab}}$ & $2,65 \pm 0,95^{\mathrm{a}}$ \\
\hline & CAT(U/g) & $84,20 \pm 5,58$ & $121,50 \pm 12,09^{\mathrm{a}}$ & $59,76 \pm 10,31^{\mathrm{a}}$ & $24,92 \pm 3,97^{\mathrm{a}}$ & $39,66 \pm 5,15^{\mathrm{ab}}$ & $138,70 \pm 4,13^{\mathrm{ab}}$ \\
\hline & $\mathrm{GPx}(\mathrm{U} / \mathrm{g})$ & $1437,14 \pm 24,88$ & $1214,55 \pm 101,37^{\mathrm{a}}$ & $1423,81 \pm 56,11$ & $1428,35 \pm 77,68$ & $1325,69 \pm 86,63^{a}$ & $1356,85 \pm 139,36$ \\
\hline & $\mathrm{SOD}(\mathrm{U} / \mathrm{g})$ & $2225,95 \pm 18,55$ & $2234,60 \pm 22,73$ & $2251,96 \pm 16,04^{\mathrm{a}}$ & $2228,48 \pm 29,47$ & $2230,33 \pm 19,36$ & $2263,25 \pm 7,39^{\mathrm{ab}}$ \\
\hline \multirow{7}{*}{ 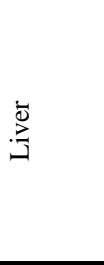 } & $\mathrm{MDA}(\mathrm{nmol} / \mathrm{g})$ & $26,98 \pm 3,08$ & $31,73 \pm 1,63 a$ & $17,09 \pm 2,80 \mathrm{a}$ & $12,69 \pm 2,91 \mathrm{a}$ & $17,74 \pm 1,08 \mathrm{ab}$ & $23,63 \pm 2,23 b$ \\
\hline & $\mathrm{GSH}(\mathrm{mg} / \mathrm{g})$ & $95,54 \pm 2,30$ & $88,25 \pm 9,54$ & $95,85 \pm 6,47$ & $89,13 \pm 4,23 a$ & $87,03 \pm 5,18 \mathrm{a}$ & $88,20 \pm 5,95 \mathrm{a}$ \\
\hline & GST(U/g) & $85,60 \pm 4,17$ & $78,52 \pm 8,22$ & $84,85 \pm 6,33$ & $86,31 \pm 9,62$ & $70,24 \pm 8,45 \mathrm{ab}$ & $98,81 \pm 6,77 \mathrm{ab}$ \\
\hline & PON1(U/100g) & $25,93 \pm 2,38$ & $20,35 \pm 2,87 \mathrm{a}$ & $15,62 \pm 1,75 \mathrm{a}$ & $23,95 \pm 2,19$ & $26,02 \pm 0,98 b$ & $16,05 \pm 2,05 \mathrm{ab}$ \\
\hline & CAT(U/g) & $151,93 \pm 16,31$ & $141,38 \pm 5,60$ & $68,34 \pm 4,23 \mathrm{a}$ & $70,22 \pm 6,32 \mathrm{a}$ & $43,15 \pm 4,86 a b$ & $68,79 \pm 5,91 \mathrm{ab}$ \\
\hline & GPx(U/g) & $1115,23 \pm 82,92$ & $1163,07 \pm 47,54 b$ & $1084,03 \pm 39,20$ & $1067,98 \pm 68,75$ & $1091,30 \pm 51,47 \mathrm{~b}$ & $1240,60 \pm 51,92 \mathrm{ab}$ \\
\hline & $\mathrm{SOD}(\mathrm{U} / \mathrm{g})$ & $2234,39 \pm 28,05$ & $2268,65 \pm 12,44 a$ & $2220,13 \pm 14,16$ & $2211,06 \pm 16,05$ & $2247,80 \pm 23,04$ & $2248,92 \pm 22,82$ \\
\hline
\end{tabular}

Today, many natural products molecules of plants have been using rather than synthetic drugs as medicinal treatment agents. It is thought that the preventive molecules in plants protect to against harmful physical and chemical environmental affects by via strengthen the body's defense system due to have mainly properties of antitumor, antioxidant and anticancer substances. Therefore, to changing of the synthetic food additives with natural antioxidants is also increasing the recent efforts towards plant treatments. Also, this situation is resulting from functional foods content through their specific components and therapeutic effect. Hence, as $C$ orientalis prevention role, under the hepatoprotective effects and chemopreventive, can be considered as liver and kidney damage serum biomarkers as serum AST, ALT and LDH enzymes activities, TP, TC, CRE and urea levels. With regard to antioxidant capacity, it can 
consider as ADSCs and MDA content of the various tissues samples.

As shown in the Table $\mathrm{I}, \mathrm{CCl}_{4}$ caused significanty an increse in the levels of AST, ALT, and LDH activities as compared with the control rats whereas the plant fruit extract supplementations diets caused a significant decrease in these biomarkers in comparison to $\mathrm{CCl}_{4}$ group rats. The reasons for such effect of $\mathrm{CCl}_{4}$ and the plant fruit extract were not certainly understood based on the present data. However, it is known that liver damage biomarkers such as AST, ALT and LDH have been considered as indicators of the hepatic cell dysfunction and degeneration. Further, the increase of LDH, AST and ALT activities in serum is estimate mainly due to the permeate of these enzymes from the hepatocytes cytosol into the blood stream by hepatocellular destruction or necrosis occured in liver [26]. Therefore, these data indicate that while $\mathrm{CCl}_{4}$ might have lead to the inducing of the enzymes into plasma because of autolytic breakdown or hepatic necrosis, the plant fruit extract supplementation posses protection against $\mathrm{CCl}_{4}$ induced liver injury that may result in development of liver damage.

On the other hands, the tissue samples as antioxidant capacity as efficiency indicator can be considered from the antioxidant enzymes GST, PON1, CAT, SOD, GPx, activities and GSH and MDA content. The present study demonstrated that the extract could have antioxidative role in rats. This was resulted from that the obvious of the MDA concentration in the tissues of the hawthorn fruit extract supplemented groups lower than $\mathrm{CCl}_{4}$ group. According to the obtained results, the MDA content increasion in the tissues of $\mathrm{CCl}_{4}$ was a significant as competed to control group whereas the MDA contents of the plant fruit extract suplementation group significantly decreased in compared to that of $\mathrm{CCl}_{4}$ group (Table II). The obvious such effect of $\mathrm{CCl}_{4}$ and the hawthorn extract additions diet are not also exactly understood at the moment. However, it can be say that the increasion of MDA content in the $\mathrm{CCl}_{4}$ group might have a resulting of the increased of reactive oxygen system (ROS) as a result of oxidative stress condition caused by $\mathrm{CCl}_{4}$ intoxication whereas the hawthorn extract supplementation diet have posses protection the role against $\mathrm{CCl}_{4}$ induced ROS. Previous studies accordance with our results had been showed that $\mathrm{CCl}_{4}$ is hepatocellular destruction or necrosis occured in liver or damage causing in vital organs like liver [27-30]. The protective and antioxidatnt properties of the plant fruit extract may be attribute to active phytochemicals such as terpenoids, flavonoids, vitamins, simple phenols, carotenoids, lignans, alkaloids and phenolic acids [3]. Also, the excessive production of ROS causing by $\mathrm{CCl}_{4}$ on liver intoxication might have been provoke a severe increase of MDA content in the tissues. [31]. It have been reported that the serious over production of ROS such as singlet oxygen and $\mathrm{H}_{2} \mathrm{O}_{2}$ as a resulting liver intoxication of consumption of some xenobiotics can be easily converted to reactive $\mathrm{OH}$ radical by different machanism. Furthermore, it is known that severe reactive $\mathrm{OH}$ radicals can initiate lipid peroxidation in tissues and MDA, which is a major peroxidized product of polyunsaturated fatty acids [4]. On the other hands, it is known that the increasion of MDA level, final product of lipid peroxidation, is an major indicator of lipid peroxidation [32]. With regard to antioxidant capacity of the plant fruit extract, the enzymes activity and GSH level were observed as fluctuate at significant levels in the $\mathrm{CCl}_{4}$ group whereas the administration of the extract supplementations also restored the the fluctuated ADSCs in the tisues to near normal levels. The such effect of functions of plant fruit extract supplemented diet are not exactly state of putting forward at the now. But, ROS as a result of oxidative stress condition caused by $\mathrm{CCl}_{4}$ intoxication might have been induced the the ADSCs in the rats tissues during exposure to $\mathrm{CCl}_{4}$. Further, the fluctuation of ADSCs may reflect an adaptive change against $\mathrm{CCl}_{4}$ induced ROS toxicity [31]. The increase of ADSCs are known to serve as protective responses to eliminate xenobiotics intoxication too [33]. Therefore, the existence of induce of ADSCs might have been a result of an adaptation of organisms too. Also, the reasons for such effect might have been due to antioxidant capacity of the plant fruit extract supplementations [7,9-11].

\section{CONCLUSION}

The study showed that the $\mathrm{CCl}_{4}$ exposuration gave rise to a significant increase of serum liver damage biomarkers, lipid peroxidation and fluctuate ADSCs in rat. But, the administration of the supplemented extract diet restored to normal the levels of serum enzymes, the fluctuated ADSCs and the increased MDA content. The data obtained by this survey may be concluded that there is a protective feature, and has antioxidant activity of the plant fruit extract nutrition in the rats. In spite of everything, the results recommends that systematic intake of the functional food may be useful for the prevention of chronic degenerative liver diseases.

\section{Acknowledgements}

The authors are thanks to the Scientific Research Projects Coordination Unit of Van Yuzuncu Yil University for the financial support during the research with VYYÜ-BAP-FYL-2017-5755 code number. The authors have declared that there is no conflict of interest. IC was the main moderator of the study. MA performed the biochemical analyszis and experimental treatments in this study.

\section{REFERENCES}

[1] Yu LL, Zhou KK, Parry J. Antioxidant properties of cold pressed black caraway, carrot, cranberry, and hemp seed oils. Food Chem 2005; 91: 723-729.

[2] Sacchetti G, Maietti S, Muzzoli M, Scaglianti M, Manfredini S, Radice M. et al. Comparative evaluation of 11 essential oils of different origin as functional antioxidants, antiradicals and antimicrobials in foods. Food Chemi 2005; 9: 621632.

[3] Liu F, Ng TB. Antioxidative and free radical scavenging activities of selected medicinal herbs. Life Science 2000; 66: 725-735. 
[4] Halliwell B. Oxidative stress, nutrition and health. Experimental strategies for optimization of nutritional antioxidant intake in humans. Free Radic Res 1996; 25: 57-74.

[5] Vendemiale G, Grattagliano I, Altomare E. An update on the role of free radicals and antioxidant defense in human disease. Int J Clin Lab Res 1999; 29: 49-55.

[6] Christensen KI. Revision of Crataegus sect. Crataegus and Nothosect. Cratae guineae (Rosaceae-Maloideae) in the Old World. Syst. Bot. Monograms 1992; 35: 1-199.

[7] Ljubuncic P, Portnaya I, Cogan U, Azaizeh H, Bomzon A Antioxidant activity of Crataegus aronia aqueous extract used in traditional Arab medicine in Israel. J Ethnopharmacol 2005; 101: 153-161.

[8] Baytop T. Treatment with plants in Turkey. Istanbul University Publication No. 3255, Istanbul; 1984.

[9] [9] Bahorun T, Trotin F. Antioxidant activities of Crataegus monogyna extracts. Planta Med 1994; 60: 323-326.

[10] Bahorun T, Greiser B. Oxygen species scavenging activity of phenolic extracts from hawthorn fresh plant organs and pharmaceutical preparations. Arzneimittel-Forsch 1996; 46: 1086-1089.

[11] Rakotoarison DA, Greissier B. Antioxidant activities of phenolic extracts from flowers, in vitro callus and cell suspension cultures of Crataegus monogyna. Pharmazie 1997; 52: 60-4.

[12] Horoz M, Gok E, Genctoy G, Ozcan T, Olmaz R, Akca M, Kiykim A, Gurses I. Crataegus orientalis Associated Multiorgan Hypersensitivity Reaction and Acute Renal Failure. Internal Medicine 2008; 47: 2039-2042.

[13] Arslan R, Bor Z, Bektas N, Meriçli AH, Oztur Y. Antithrombotic effects of ethanol extract of Crataegus orientalis in the carrageenan-induced mice tail thrombosis model. Thromb Res 2011; 127: 210-213.

[14] Dalar A, Konczak I. Phenolic contents, antioxidant capacities and inhibitory activities against key metabolic syndrome relevant enzymes of herbal teas from Eastern Anatolia. Ind Crop Prod 2013; 44: 383-390.

[15] Kim SH, Cheon HJ, Yun N, Oh ST, Shin E, Shim KS. et al. Protective effect of a mixture of Aloe vera and Silybum marianum against carbon tetrachloride-induced acute hepatotoxicity and liver fibrosis, J Pharmacol Sci 2009; 109(1): 119-27.

[16] Celik I, Temur A, Isık I. Hepatoprotective role and antioxidant capacity of pomegranate (Punica granatum L.) flowers infusion against trichloroacetic acid-exposed in rats. Food Chem Toxicol 2009; 47: 145-149.

[17] Dogan A, Celik I. Hepatoprotective and antioxidant activities of grape seeds against ethanol-induced oxidative stress in rats. Br J Nutr 2011; 107: 45-51.

[18] Yurt B, Celik I. Hepatoprotective effect and antioxidant role of sun, sulphited-dried apricot (Prunus armeniaca L.) and its kernel against ethanol-induced oxidative stress in rats. Food Chem Toxicol 2011; 49(2): 508-513.

[19] Jain SK, McVie R, Duett J, Herbst JJ. Erythrocyte membrane lipid peroxidation and glycolylated hemoglobin in diabetes. Diabetes 1989; 38: 15391543.

[20] Beutler E, Dubon O, Kelly M. Improved method for the determination of blood glutathione. $\mathrm{J} \mathrm{Lab}$ Clin Med 1963; 61: 882-888.

[21] Mannervik B, Guthenberg C. Glutathione Stransferase (Human Plasenta). Method Enzymol 1981; 77: 231-235.

[22] Paglia DE, Valentine WN. Studies on quantitative and qualitative characterization of erythrocyte glutathione peroxidase. J Lab Clin Med 1967; 70: 158.

[23] McCord JM, Fridovich I Superoxide dismutase, Anenzymatic function for erythrocuprein (hemocuprein). J Biol Chem 1969; 244: 6049-6053.

[24] Aebi H Catalase, In Methods of Enzymatic Analysis (Bergemeyer, H U.,ed) New York, NY, US: Academic Press: 1974. p. 673-684.

[25] [25] Haagen L, Brock AA new automated method for phenotyping arylesterase (E.C. 3.1.1.2) based upon inhibition of enzymatic hydrolysis of 4nitrophenyl acetate by phenyl acetate. Eur J Clin Chem Clin Biochem 1992; 30:391-395.

[26] Sallie R, Tredger JM, William R. Drugs and the liver. Part I. Testing liver function. Biopharm Drug Disp 1991; 112:251-259.

[27] Recknagel RO. A new direction in the study of carbon tetrachloride hepatotoxicity. Life Science 198; 33(5): 401-8.

[28] Turkdogan MK, Ozbek H, Yener Z, Tuncer I, Uygan I, Ceylan E. The role of Urtica dioica and Nigella sativa in the prevention of carbon tetrachloride induced hepatotoxicity in rats. Phytother Res 2003; 17: 942-946.

[29] Suzek H, Celik I, Dogan A, Yildirim S. (2016) Protective effect and antioxidant role of sweetgum (Liquidambar orientalis) oil against carbon tetrachloride-induced hepatotoxicity and oxidative stress in rats. Pharm Biol 54 (3): 451-457.

[30] Suzek H, Celik I, Dogan A. Nephroprotective Hepatoprotective Potential and Antioxidant Role of Carob Pods (Cerotonia siliqua L.) against Carbon Tetrachloride-induced Toxicity in Rats. Ind $\mathbf{J}$ Pharm Edu Res 2017; 51(2). 312-320.

[31] Chidambara Murthy KN, Rajesha J, Vanitha A, Swamy MM, Ravishankar GA. Protective effect of Dunaliella salina-a marine micro alga, against carbon tetrachloride-induced hepatotoxicity in rats. Hepatol Rese 2005; 33(4):313-9.

[32] Freeman BA, Crapo JD. Hyperoxia increases oxygen radical production in rat lung and lung mitochondria. J Biol Chem 1981; 256: 1098610992.

[33] Smith GJ, Litwack G. Roles of ligandin and the glutathione $\mathrm{S}$-transferases in binding steroid metabolites, carcinogens and other compounds. Rev Biochem Toxicol 1980; 2: 1-47. 